\title{
INTRANEURAL BRANCHES OF THE CENTRAL RETINAL ARTERY*
}

\author{
BY \\ MICHAEL J. BLUNT \\ From the School of Anatomy, University of New South Wales, Sydney
}

\begin{abstract}
A RECENT publication concerned with the central artery of the retina (François and Neetens, 1963†) exhibits several inconsistencies which call for comment. The authors state that the central retinal artery may branch within the optic nerve, but that any such branches are not distributed to the tissues of the nerve: they claim to have demonstrated in ten out of 31 optic nerves a separate artery which constitutes an axial vascular system feeding the capillary bed within the nerve, and which they call "the central artery of the optic nerve". Except that the frequency of occurrence of this latter vessel is mentioned, the claims made recapitulate those of earlier papers by the same authors (François and Neetens, 1954, 1956; François, Neetens, and Collette, 1955). They are made in the context of other recent publications on the blood supply of the optic nerve, at least one very relevant paper (Wybar, 1956) being, however, entirely disregarded.
\end{abstract}

\section{Comment}

The above statements cannot be substantiated in view of the unequivocal published photographic evidence demonstrating an intraneural distribution of the central retinal artery, revealed not only by different injection techniques but by sodium nitroprusside-benzidine staining (Blunt, 1956; Steele and Blunt, 1956; Wybar, 1956; Singh and Dass, 1960).

The experimental evidence provided by François and Neetens (1963) in support of their findings is scarcely of a significant nature. They injected the ophthalmic artery after ligation of the central retinal artery and claimed to produce complete filling of the capillary bed of the optic nerve. A photograph published in support of these findings is captioned as follows: "Fig. 7. Transverse section of human optic nerve. Anterior part. Thorotrast injection. $\times 14$ ". In fact, however (Singh, 1963), the illustration in question is clearly an enlarged and reversed print of an earlier figure (François, Neetens, and Collette, 1955), the caption to which is: "Fig. 6-Or. $\times 22$. Posterior part. Transverse section (slightly oblique). Meshes a little wider centrally".

* Received for publication May 20, 1963.

$\dagger$ See correction "A Note on the Vascularization of the Optic Nerve". J. François and A. Neetens, Brit. J. Ophthal. (1963) 47, 380.-Ed. 
In fact, an illustration earlier presented as a micro-angiograph of the posterior part of the optic nerve (posterior third) is now claimed to be a section through the anterior part of the nerve injected in the circumstances outlined above, attention being drawn to the fact that "the central retinal artery is not shown, but the optic nerve is completely and excellently filled".

In view of such a very evident confusion of material it may be doubted if these results warrant any serious consideration. In fact, their significance would be quite uncertain even if there had been no such confusion. That the capillary bed of the optic nerve might be injected in the absence of filling of the central retinal artery could well demonstrate nothing more than the adequacy of capillary anastomoses between the central and pial capillary systems.

No evidence emerges, therefore, in support of the authors' claim that the central retinal artery is not distributed to the tissues of the optic nerve, other than their failure to demonstrate a distribution already convincingly shown by many other investigators. It is widely recognized that far more reliance may be placed upon the positive than upon the purely negative results of injection techniques, and in view of the positive evidence available, the inability of François and Neetens to demonstrate an intraneural distribution of the branches of the central retinal artery is most readily explicable in terms of an inadequacy of the injection techniques they employed.

\section{REFERENCES}

Blunt, M. J. (1956). Proc. roy. Soc. Med., 49, 433.

François, J., and NeETENS, A. (1954). Brit. J. Ophthal., 38, 472. (1956). Ibid., 40, 45. (1963). Ibid., 47, 21; 380.

ST,, and ColletTe, J. M. (1955). Ibid., 39, 320.

SingH, S. (1963). Personal communication. and DAss, R. (1960). Brit. J. Ophthal., 44, 280.

Steele, E. J., and Blunt, M. J. (1956). J. Anat. (Lond.), 90, 486.

WyBAR, K. C. (1956). Brit. J. Ophthal., 40, 65. 